\title{
Correction \\ Correction: Tickner, Z.J.; Farzan, M. Riboswitches for Controlled Expression of Therapeutic Transgenes Delivered by Adeno-Associated Viral Vectors. Pharmaceuticals 2021, 14, 554
}

\author{
Zachary J. Tickner $1, *(\mathbb{D})$ and Michael Farzan 1,2 \\ 1 Department of Immunology and Microbiology, The Scripps Research Institute, Jupiter, FL 33458, USA; \\ mfarzan@scripps.edu \\ 2 Emmune, Inc., Jupiter, FL 33458, USA \\ * Correspondence: ztickner@scripps.edu
}

check for updates

Citation: Tickner, Z.J.; Farzan, M Correction: Tickner, Z.J.; Farzan, M Riboswitches for Controlled

Expression of Therapeutic Transgenes Delivered by Adeno-Associated Viral Vectors. Pharmaceuticals 2021, 14, 554. Pharmaceuticals 2021, 14, 1271.

https://doi.org/10.3390/ph14121271

Received: 8 September 2021

Accepted: 5 November 2021

Published: 6 December 2021

Publisher's Note: MDPI stays neutral with regard to jurisdictional claims in published maps and institutional affiliations.

Copyright: (c) 2021 by the authors. Licensee MDPI, Basel, Switzerland. This article is an open access article distributed under the terms and conditions of the Creative Commons Attribution (CC BY) license (https:// creativecommons.org/licenses/by/ $4.0 /)$.

\section{Missing Citation}

In the original article, Renzl, C.; Kakoti, A.; Mayer, G. Aptamer-Mediated Reversible Transactivation of Gene Expression by Light. Angew. Chem. Int. Ed. 2020, 59, 22414, doi:10.1002/anie.202009240 was not cited [1]. The citation has now been inserted in Section 2.8: Regulation of CRISPR-Cas Activity by Riboswitches, paragraph 2, and should read: A particularly interesting case was recently reported by Renzl et al., who incorporated aptamers to the photoreceptor PAL into gRNAs and demonstrated 546-fold regulation of mRNA levels in response to light in HeLa cells [190].

\section{Reference}

1. Tickner, Z.J.; Farzan, M. Riboswitches for Controlled Expression of Therapeutic Transgenes Delivered by Adeno-Associated Viral Vectors. Pharmaceuticals 2021, 14, 554. [CrossRef] [PubMed] 